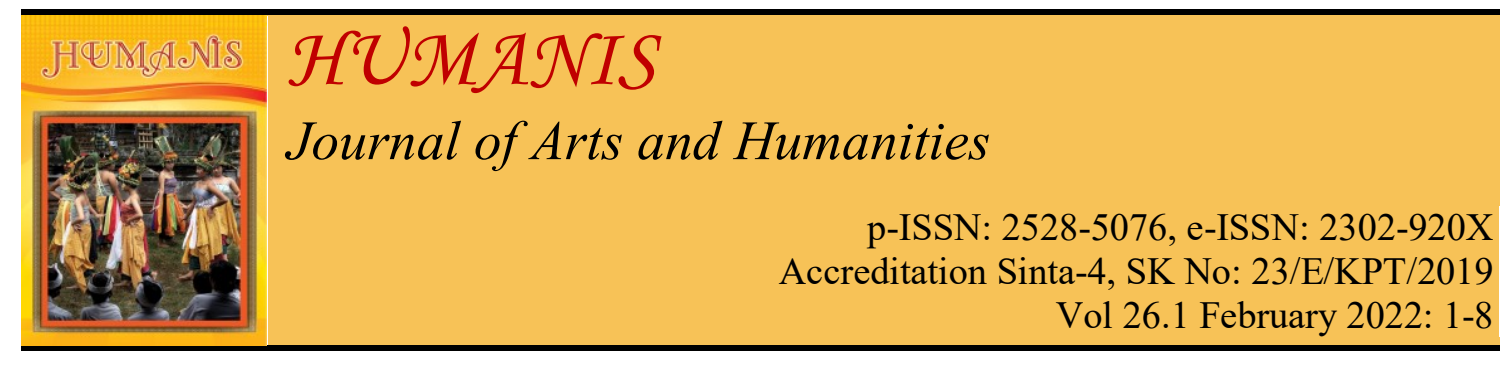

\title{
Born As Subaltern or To Become Subaltern: An Exploration of Subalternity in Dana Johnson's Because That's Just Easier
}

\author{
Alireza Sardari \\ Payame Noor University, Tehran, Iran \\ Correspondence Email: alireza.sardari7@gmail.com
}

\begin{tabular}{|c|c|}
\hline Article Info & Abstract \\
\hline $\begin{array}{l}\text { Submitted: } 13^{\text {th }} \text { December } 2021 \\
\text { Revised: } 28^{\text {th }} \text { January } 2022 \\
\text { Accepted: } 12^{\text {th }} \text { February } 2022\end{array}$ & $\begin{array}{l}\text { The possibility to become subaltern in social relationships is an } \\
\text { important issue in postcolonial studies. This article aims to } \\
\text { investigate the representations of subalternity, and the } \\
\text { characters' reactions for being portrayed as subaltern in Dana }\end{array}$ \\
\hline $\begin{array}{l}\text { Keywords: } \\
\text { normalization of subalternity, } \\
\text { subaltern studies, cultural } \\
\text { studies, G. C. Spivak, } \\
\text { postcolonial theory. }\end{array}$ & $\begin{array}{l}\text { Johnson's story Because That's Just Easier (2016). Spivak's } \\
\text { concept of subaltern will be consulted. Through the analysis } \\
\text { process, I will introduce a process which I call 'Normalization } \\
\text { of Subalternity' that spotlights the issue of subalternity in } \\
\text { human relationships. The results indicate that subalternity is a } \\
\text { social-cultural construct, not an overnight phenomenon. Two }\end{array}$ \\
\hline $\begin{array}{l}\text { Corresponding Author: Alireza } \\
\text { Sardari } \\
\text { Email: } \\
\text { alireza.sardari7@gmail.com }\end{array}$ & $\begin{array}{l}\text { characters, that is, the man lying on the side walk and the six- } \\
\text { year-old girl (Dakota) have both become subaltern because } \\
\text { their suffering is the subject of others' getting-used-to. The } \\
\text { results also show that Dakota is expected and accepted to be } \\
\text { vulnerable, but she deconstructs this mentality and rejects }\end{array}$ \\
\hline $\begin{array}{l}\text { DOI: } \\
\text { https://doi.org/10.24843/JH.20 } \\
\text { 22.v26.i01.p01 }\end{array}$ & $\begin{array}{l}\text { subalternity. She critiques her parents (and others alike) for } \\
\text { getting used to the suffering of humanity. }\end{array}$ \\
\hline
\end{tabular}

\section{INTRODUCTION}

Just as human relationship is a fact, so is the possibility of becoming subaltern in these relationships. The inequalities in human relations that result from binary oppositions such as man/woman, adult/child, male/female, etc., turn the subalternity_from possibility_ into actuality. This cycle is repeated ad nauseam that the existence of subaltern (that is, someone whom others see as inferior than themselves) seems normal to the extent that the absence of the subaltern in human relations seems abnormal. For example, people in a society may give less credit to a child's narrative than an adult's narrative about the same issue because $\mathrm{s} / \mathrm{he}$ is a child, even if the child is right and the adult is wrong. This cycle is passed down from generation to generation that becomes part of culture.

Dana Johnson, born in 1967 in Los Angeles is an American writer and Associate Professor of English at the University of Southern California. In her short stories, Johnson mainly examines "large issues - love, class, race - and how they influence and define our most intimate moments" (Description, 2016). In an interview with Natashia Deón, Jonson comments, "I reject the idea that as a black woman, I'm relegated to writing black woman exclusively. That is not what being a writer is for me" (Deón, 
2016). Elsewhere in an interview, Johnson states, "I wanted to write about humans. That's what I did and that's what I do." (Caraballo, 2017). Her famous works are Break Any Woman Down (2001), a collection of nine short stories that earned her the Flannery O'Connor Award for Short Fiction; Elsewhere, California: A Novel (2012), and In the Not Quite Dark: Stories (2016). Johnson was also Finalist for both Hurston/Wright Foundation Award, 2002-2003, and for Patterson Fiction Prize, 2002-2003.

Because That's Just Easier is a short story in the collection In the Not Quite Dark: Stories (2016). It is about Frida and her husband Jackson, and their sixyear old daughter Dakota. They live in downtown Los Angeles where their loft is only two streets up from a poor neighborhood. One night, Jackson and Frida are watching a movie about Zombies. Although Jackson loves the movie, but Frida is scared from the beginning. When she turns around, she sees Dakota standing behind them watching the movie. Dakota says, "those people look like the people on the street" (Johnson, 2016: 73). Jackson responds: no, they are different. "Dakota started crying, and saying that she didn't want to be a zombie, like the people outside" (73). Jackson criticizes Frida for too much babying their daughter. He believes that they should go outside and enjoy walking on the streets like others. It is enough being agoraphobic. "'It's a beautiful night,' he said, crouching down to Dakota's level. 'Bubs, you need to be a big girl about this", (Johnson, 2016: 75). Returning to their home, they pass by a man who is lying in the middle of the sidewalk. They have a conversation about if he is dead or not.

This article aims to analyze the subalternity process in Dana Johnson's Because That's Just Easier. Spivak's critical concept of 'subaltern' reflected in her article "Can the Subaltern Speak" (1988) will be consulted. The following questions will be answered: First, what is the representation of Subalternity? Second, how the character(s) react for being portrayed as subaltern?

\section{METHOD AND THEORY}

Postcolonial theory is inherently political, social and cultural that focuses on issues such as race, otherness, power relations, and marginality in society. It "invokes ideas of social justice, emancipation and democracy in order to oppose oppressive structures of racism, discrimination and exploitation" (Nayar, 2010: 4). Therefore, Postcolonial theory seeks to strengthen the voice of the marginalized and deprived sections of the society, and seeks to challenge the legacy of colonialism and racism in all its forms. In that regard, Nayar (2010) remarks that postcolonialism "finds its origins in the thoughts and theories of anti-colonial movements . . . in Africa and Asia generated ideas of political independence, colonial exploitation and identity politics which eventually grew into a substantial body of ideas in postcolonial theory and studies" (5).

Without doubt G. C. Spivak is one of the most prominent literary and cultural theorists in the present era who has demonstrated the "rhetorical and political agency of postcolonial literary texts to question and challenge the authority of colonial master narratives" (Morton, 2003: 112). Her seminal article "Can the Subaltern Speak" (1988) inaugurated an important conversation in the academia spotlighting the inequality against marginalized groups, especially women. Although Spivak is not the first theorist to use the word 'subaltern', but she definitely paved the way for its widespread application in literary/cultural studies. Antonio Gramsci was the first theorist who popularized the term 'subaltern' to describe "those classes of 
people with little political and cultural power" (Nayar, 2015: 143). In his prison notes, Gramsci underscores that "on a world scale, history is the history of the hegemonic states. The history of subaltern states is explained by the history of hegemonic states" (Gramsci, 2001: 356). That is, the hegemonic power defines the subaltern in service of hegemonic state's interests, and this definition is not necessarily realistic because when it comes to interest/benefit, the dominant power interprets, explains, or even denies facts according to their own ideology. Thus, the ruler remains the dominant power, and the weak continues living invisible on the margins for Godknows-how-long.

Spivak's 'subaltern' is her most well-known critical concept that is originally taken from the "colonial military context meaning a nonwhite soldier of inferior rank, which is used in postcolonial theory to denote a member of the colonized population" (Klages, 2012: 81). The flexibility of subaltern's meaning offers Spivak the privilege and ability to address serious issues such as patriarchy, oppression, and colonialism. Spivak uses the term 'subaltern' not only for women, but also for "lowest layers of a colonial or postcolonial society: the homeless, the day laborers, the unemployed, arguing that these subaltern populations are voiceless and invisible in both colonial and post- or neocolonial cultures" (Klages, 2012: 81). Thus, for Spivak 'subaltern' is a holistic concept encompassing the deprived, marginalized, and less privileged groups in society where their voice is not heard, and their narratives are not told. And this is important for Spivak (1988) as she writes, "In the context of colonial production, the subaltern has no history and cannot speak, the subaltern as female is even more deeply in shadow" (287). In such a monolithic system, the subaltern does not represent themselves, not that they cannot, but because they are banned to do so. Women are doubly oppressed and marginalized in the patriarchal society, and Spivak seeks to bring the marginalized to the front amplifying their voice to tell their stories of suffering and deprivation.

About Spivak's “Can the Subaltern Speak?" (1988), it should be mentioned that the dominant power generates strategies "either for economic reasons or to control indigenous populations in colonial possessions by emphasizing their difference and constructing them as inferior" (Ashcroft et al., 2013: 202). No matter how different these strategies are, they have a common goal: To push the subaltern to the margin. Spivak's article "Can the Subaltern Speak?" (1988) as a pioneer work in postcolonial studies critiqued the ignorance toward Indian women. In her article, she mainly focuses on "women as subalterns in debates between British and Indian cultures around the issue of sati or widowburning; women themselves do not participate, from either perspective, in the debate" (Klages, 2012: 81). That is, in the debates about women, women themselves have no voice and cannot represent themselves. Men's wishes have been privileged over women's needs. Women have been represented by men, spoken for by men, and decided for by men. This is where we should notice that there is a fine line between 'not being able to speak' and 'not being able to understand the speaker'. Needless to say, not listening to women's voices is rooted in the patriarchal discourse that only understands men's voices. In her article "Can the Subaltern Speak?" (1988), Spivak talks about 'Sati'. She

develops a gendered analysis of the subaltern by looking at the situation of Indian women and their representation in Western discourses, particularly in the context of 'sati' or widow sacrifice. 
Spivak argues that 'subaltern as female is even more deeply in shadow', concluding famously that 'the subaltern cannot speak'. What Spivak is suggesting is not that the subaltern does not have a voice; rather, her critical project is to question the whole representational system which attempts to retrieve the voice of the subaltern. In other words, even when intellectuals are trying to give voice to the oppressed, this act remains implicated in Western discourse - it produces subalternity and the subaltern as a passive object who is spoken for. By examining these uneven transactions between speaker and listener, Spivak wants to challenge the very production of the condition of subalternity. (Cuddon, 2013: 689)

Since the patriarchal discourse ignores the rights of women, they (women) are present in the society but this presence is limited to the subaltern role, a position predetermined by men, which of course is unchangeable. It is clear that women should have the opportunity to leave the margins. By doing so, there could be hope that their needs would not be ignored anymore. In other words,

The problem is not that the woman cannot speak as such, that no records of the subject-consciousness of women exist, but that she is assigned no position of enunciation: 'there is no space from where the subaltern (sexed) subject can speak' (CSS 129). She is allowed no subject-position, or rather, the place of the sati certainly is an enunciative position, but she is not allowed to speak: everyone else speaks for her, so that she is rewritten continuously as the object of patriarchy or of imperialism. (Young, 2004: 206)

Women cannot speak about their needs as long as they are expected to have only a passive role. Women cannot speak since they are not given any space to speak, and to be themselves without the fear of being judged. Spivak's analysis is "directed at the subjectposition of the female subaltern, whom she describes as doubly marginalized by virtue of relative economic disadvantage and gender subordination" (MooreGilbert, 2000: 80). And this unequal situation will only change if women are not marginalized anymore, and can play an independent role in the society.

\section{RESULT AND DISCUSSION}

Dana Johnson's Because That's Just Easier is mainly about subalternity, and the choices in front of us for dealing with this issue. Frida, a main character in this story, is an impeccable incarnation of agoraphobic personality who is constantly worried about bad things that may happen to her family. This characteristic is bold throughout the story. For instance, when she says "Downtown Los Angeles was a stupid place to raise a child" (Johnson, 2016: 70), it shows her coming-to-surface anxieties for living in downtown "as close to skid row as to the library in theory, and then there were the practical aspects of raising a tiny human being in a city that had the highest homeless population in the country" (Johnson, 2016: 74). Her worldview toward the world outside their home inflicts suffering on her husband Jackson, and their six-year old daughter Dakota. One night, Jackson convinced Frida to let him carry Dakota out "on his shoulders, high above the ground, . . . He promised her [Dakota] ice cream. It seemed to Frida that Dakota looked around with big gray eyes so stricken with fear, ... as if she knew the worst thing . . was about to happen" (Johnson, 2016: 75). Subalternity is a process of becoming. Parents, through their behavior, can accelerate this process in their children, 
because kids quickly internalize these behaviors. Frida prefers to remain in her comfort zone than to live among people in real life. Jackson, on the other hand, holds a different view, "I feel like a shut-in,' he often said, in his campaign to move. 'I want to live in the middle of people, people on top of me and below. On either side"' (Johnson, 2016: 71).

Because That's Just Easier is based upon adult/child duality where the sixyear-old Dakota becomes subaltern. That is, she is considered to be incognizant, and naive. One night after work, Jackson wanted to enjoy a "nice balmy walk around town. . .. 'It's a beautiful night,' he said, crouching down to Dakota's level. 'Bubs, you need to be a big girl about this" (Johnson, 2016: 75). Jackson decided that "enough was enough with this not-going-outside business, that Frida was babying their daughter too much, that no kid of his was going to become some weirdo recluse, agoraphobic wackadoo" (75). Frida, staying in her bubble of insecurity, evades the fact that escaping from reality does not change reality. It is what it is, whether we acknowledge or ignore it. Frida, by overprotecting Dakota, puts her in a process which I call 'Normalization of Subalternity' in which the six-year-old girl becomes the subaltern.

By 'Normalization of Subalternity' I mean that, sometimes people in interpersonal relationships insist on the correctness of their own thoughts. Combining this trait with being educated in a culture that distributes social roles between individuals on the basis of superior/inferior binary, results in the predetermined superiority of one side of the binary over the other. For example, man is considered superior while woman is expected and accepted to be inferior. This cycle continues (generation after generation) to the point where people naturally accept the predetermined roles based on superiority/inferiority. An example helps better understand the point: Women are usually expected to earn less than men. It is accepted by society, and it is considered normal. Thus, this issue has turned into culture. I call this process 'Normalization of Subalternity' because it seeks to make the predetermined roles (based on superiority/inferiority) as normal as possible. For example, a society (based on its dominant culture) expects the female to accept the predetermined role of inferiority and become subaltern. In Because That's Just Easier, Dakota is not born subaltern, but she undergoes the process of 'Normalization of Subalternity' and becomes subaltern. The society simultaneously expects her and accepts her to take this predetermined role.

If the subaltern is pushed to the margins, it does not mean that $\mathrm{s} /$ he has nothing to say. It does not mean that $\mathrm{s} / \mathrm{he}$ is voiceless. $\mathrm{S} /$ he becomes subaltern because there is no listening for what $\mathrm{s} / \mathrm{he}$ says. And what a big difference there is between speaking and not listening. In the story, while Jackson, Frida, and Dakota were returning home,

there was another man in the distance, lying on the sidewalk. All the people in front of them walked and parted mysteriously, and if you didn't know there was a man on the sidewalk, Frida thought, everyone would seem crazy for suddenly changing course like that, identically, almost at the last minute. (Johnson, 2016: 77)

If we don't (want to) see the subaltern, it doesn't mean that suffering doesn't exist. The suffering is still right there lying on the street while we pass by it and only care about the ice cream in our hands. We can close our eyes, but suffering of the subaltern still exists. 
They got closer to the man, lying right in the middle of the sidewalk, arms and legs spread as if he had been making snow angels on the hot concrete. When they passed him, Frida looked at her daughter and saw her big gray eyes get small and determined. ... 'Is he dead, Mama?' 'No. He's not dead,' Frida said, though she didn't know if this was true or not. She told herself that if the man were dead, people wouldn't be walking around him. 'Are you sure he's not dead?' Dakota looked back again. (Johnson, 2016: 77-78)

This story gives voice to the subaltern to speak the unspoken. And this is the message that postcolonial theory conveys: To decentralize the dominant discourse that seeks to keep the subaltern silent at the margins. This story depicts the issues that seem ordinary due to their repetition in daily life, such as a human being lying on the sidewalk. In this regard, Johnson in an interview asserts that,

In Because That's Just Easier, I wanted to examine how we can in fact become zombies ourselves in trying to forget and not see. It's incredible what I've gotten used to. When I go to other parts of the country like, for example, smaller towns in Alabama, where my husband is from, you will not see a single homeless person, and if you did, you certainly would not normalize it like we do here. ... I do think that there is a phenomenon of getting 'used' to something because it's so ubiquitous, when in another setting or situation, to see a person lying on the street immediately calls on you to ask what's wrong or if there is some way you can help. It's just clear that in our larger American cities and at the local, state, and federal government level, this issue has not been addressed in any consequential, substantial way. (Deón, 2016)

The subaltern's discourse aims to change the position of disempowered groups, and to move them from the margin to the center where everyone has the right to speak, and to be heard, not only a few. In this story, Dakota (whom no one takes seriously) speaks out against the apathy about human suffering. Jackson said,

if he were dead, he wouldn't just be lying in the middle of the sidewalk. So he's probably not. Look. We're almost home.' 'But if he's not dead,' Dakota said, turning her head again, turning her whole body. 'Can't we do something, Papa? If he's not dead, then we should help him. . .. 'If he's not dead,' Jackson said, 'then it's harder. [Dakota asks] 'Why? Can't we help him and take him somewhere?'. (Johnson, 2016: 78)

Here, she becomes the voice of human suffering. A six-year-old girl who herself is considered as subaltern becomes the voice of (another) subaltern's suffering.

Dakota looked up at Frida. 'Can't we take him to where you get the help?' 'Well.' Frida knelt down too. 'You can't do that for everybody, baby.' 'No,' Dakota said. She stomped her foot. She did this whenever she got frustrated. It was just her way of saying everybody and everything is so stupid. 'I'm talking about just him.' 'That's hard to do, Honey.' Both Frida and Jackson stood up. 'Why?' Dakota said. She pleaded. She really wanted to know. Her little shoulders slumped. (Johnson, 2016: 78)

The question is not whether subaltern speaks or not, because $\mathrm{s} / \mathrm{he}$ 
speaks but $\mathrm{s} /$ he is not heard, and what is easier than not hearing or pretending not to hear him/her. The problem raises when we don't listen to the subaltern, and we don't try to understand them. Dakota does not tolerate seeing a human being lying on the sidewalk while others pass by his suffering. In Dakota's worldview, humans help each other. This is what adults teach kids in kindergarten: To soothe another's grief, and to listen to another's stories. But when it comes to real life, adults forget their own teachings. In this story, Dakota shows empathy while others successfully get used to the human suffering. This is reminiscent of a famous Persian poem,

The members of the human race are limbs one to another,

for at creation they were of one essence.

When one limb is pained by fate, the others cannot rest. (Sa'di of Shiraz, 2008: 22)

It is true. No matter where we live or where we belong to. At the end of the day, it is the good feeling of helping each other (no matter where, when, or how) that make us feel connected as human beings.

\section{CONSLUSION}

This article investigated the process of Subalternity in Dana Johnson's Because That's Just Easier (2016). Through the analysis process, Spivak's concept of subaltern reflected in her article "Can the Subaltern Speak" (1988) was consulted.

To answer the first question, the results indicate that we are not born subaltern, we become subaltern. The subaltern is the potential product of human relationship that becomes an actuality through the process which I call 'Normalization of Subalternity'. This process is a social-cultural construct. That is, it does not happen overnight. The dominant culture and ideology produce this cultural-social process. The man who is lying on the sidewalk has become subaltern because others pass by him indifferently. And the six-year-old Dakota has also become subaltern in the sense that she is underrated. That is, she is considered as a helpless, defenceless, and vulnerable girl. These two characters have experienced a common pain: Subalternity.

To answer the second question, the results show that Dakota is expected and accepted to be a dependent girl who needs permanent caring. But, Dakota rejects subalternity. She deconstructs the mentality about her unawareness of the life outside home. She openly asks her parents serious questions such as "Is he dead, Mama?" (Johnson, 2016: 77). "Are you sure he's not dead?" (78). "Can't we do something, Papa? If he's not dead, then we should help him" (78). "Can't we help him and take him somewhere?" (78). She critiques her parents (and others) for getting used to another human's suffering. She decentralizes her parent's discourse. On the other hand, she centralizes her own discourse that is 'let's help the subaltern'. Yes, subalternity is not a choice, it is a compulsion. And Dakota represents those who can do more, but are expected to do less.

\section{REFERENCES}

Ashcroft, B., Griffiths, G., \& Tiffin, H. (2013). Postcolonial Studies: The Key Concepts (3rd ed.). Routledge.

Caraballo, L. (2017, August 23). Litdish: Dana Johnson, Author. Https://Lunchticket.Org. https://lunchticket.org/litdish-danajohnson-author/ 
Cuddon, J. A. (2013). A Dictionary of Literary Terms and Literary Theory (M. Birchwood, V. Velickovic, M. Dines, \& S. Fiske, Eds.; 5th ed.). Wiley-Blackwell.

Deón, N. (2016, October 22). Who Gets to Tell Stories?

Https://Lareviewofbooks.Org. https://lareviewofbooks.org/article/ gets-tell-stories/

Description: In the not quite dark. (2016).

Https://Search.Schlowlibrary.Org. https://search.schlowlibrary.org/Re cord/390320/Description\#record

Gramsci, A. (2001). Further Selections from the Prison Notebooks (D. Boothman, Ed. \& Trans.). The Electric Book Company.

Johnson, D. (2016). Because That's Just Easier. In In The Not Quite Dark (pp. 67-79). Counterpoint.

Klages, M. (2012). Key Terms in Literary Theory. Continuum.

Moore-Gilbert, B. (2000). Postcolonial Theory: Contexts, Practices, Politics. Verso.

Morton, S. (2003). Gayatri Chakravorty Spivak. Routledge.

Nayar, P. K. (2010). Postcolonialism: A Guide for the Perplexed. Continuum.

Nayar, P. K. (2015). The Postcolonial Studies Dictionary. Wiley Blackwell.

Sa'di of Shiraz, S. (2008). Chapter One: The Conduct of Kings. In The
Gulistan (Rose Garden) of Sa'di: Bilingual English and Persian Edition with Vocabulary. (W. M. Thackston, Trans.) (pp. 12-45). Ibex Publishers, Inc.

Spivak, G. C. (1988). Can the Subaltern Speak? In C. Nelson \& L. Grossberg (Eds.), Marxism and the Interpretation of Culture (pp. 271313). Macmillan Education.

Young, R. J. C. (2004). White Mythologies: Writing History and the West (2nd ed.). Routledge. 